\title{
The Effect of the Internet in the Book Retail Market
}

\author{
Lulu Yang \\ College of Business \\ Hunan Agricultural University \\ Changsha 410128, China \\ E-mail: yl1525@hotmail.com
}

\begin{abstract}
There are many new challenges for small businesses in the 21st century, especially the extensive use of Internet. It leads that the competition of small businesses, such as the book retail market, is fierce and getting fiercer. How the internet affect on the book retail market? In this paper, I will focuses on three different parts that Internet affects on the book retail market for both buyers and sellers. This paper is organized as follows: at first, I will introduce three main different issues about the effect of the Internet. At the same time I will cite ample data to illustrate the effect. Then I will illustrate the future of book retail market. Finally, I will summarize my points.
\end{abstract}

Keywords: Book retail market, Internet, Effect

\section{Introduction}

About ten years ago, dealing with the retail trade was wonderfully simple for publishers. They had their own dedicated retail outlets (bookshops) that actually in the main sold only books. Meanwhile for buyers there were only two ways to buy a book, either order it via a catalogue or book club or, more commonly, simply go to a shop, pay money and take it home in a bag. Now following an explosion in the use of the internet, the buyers and sellers have been affected by this expansion. "The Internet has changed the way your customers shop, and that means you must change the way you market your store." (Higgins Les, 2000)

\section{The effect of the Internet}

Nowadays, customer can visit the online bookshops, view a book, read its blurb, browse through the shop's collection, make a selection, and pay for the book online. The book may be delivered physically or, in some cases, downloaded onto the buyer's computer. And as many of the orders are international, this raises challenging issues for existing book retail market. At the same time, most publishers now have a web site for direct selling. The publishing world is in a mad scramble to get onto the Internet However, they argue that the Internet is producing incremental sales rather than taking business from bookshops. In other words those web sites are growing, rather than replacing, the market. For example, it's clear to see at moment that Internet bookshops are able to offer unlimited shelf space and consequently a much larger number of titles (average about 1.5 million) than even the largest physical bookshop (average 150000). They can also do, all the time, what no physical bookshop can possibly achieve with similar consistency, organize, recommend and cross refer according to the tastes of the individual customer, with the added benefit of affects the book retail market?

\subsection{Increasing price competition}

When we look at the EBay (www.ebay.co.uk) or Amazon (www.amazon.com), the popular Internet shop in the world, we can find certain price much cheaper than in the bookshop or there are different price for the same book. It may seem clear that the Internet push markets toward a greater degree of price competition. Internet market always uses dynamic pricing that means the price is regularly updated. It's the benefits to buyers of greater price competition. A low price clearly gives an motivation to buy the books on line rather than the physical stores. Another side lower search costs in Internet markets will make it easier for buyers to find low-cost sellers, and thus will promote price competition among 
sellers. In particular, to the internet book shop it have a brighter future in a wired world and they can more easily be searched for and discovered, as search costs online are less determined by geography.

However, price competition also pushes sellers to have to think about how to avoid competing purely on price. For example, the new book can be reformatted and distributed almost costless via the Internet, while payment and distribution technologies are reducing the transaction costs for their commercial exchange. This creates new opportunities for repackaging content through strategies such as bundling, site licensing, subscriptions, rentals, differential pricing and per-use fees.

\subsection{Reducing costs}

The Internet market can reduce costs, including fixed costs and variable costs, for both buyers and sellers. To buyers, these costs include the opportunity cost of time spent searching, as well as associated expenditures such as driving, telephone calls, computer fees and magazine subscriptions. Similarly, sellers face costs in identifying qualified buyers for their products, such as market research, advertising, and sales calls. For instance, quite a few internet-based technologies lower buyer search costs. Many sites help buyers identify appropriate seller offerings. However, on-line agents help buyers identify the most desirable prices and product offerings without requiring them to take specific action. Internet can also lower the cost to buyers of acquiring information about the reputations of market participants. Such reputations may be provided as part of the marketplace. The Internet lowers seller search costs as well, by allowing sellers to communicate product information cost effectively to potential buyers, and by offering sellers new ways to reach buyers through targeted advertising and one-on-one marketing.

By reducing costs on both sides of the market, it appears likely that buyers will be able to consider more product offerings and will identify and purchase products that better match their needs, with a resulting increase in economic efficiency. But the reduction in costs combined with new capabilities of information technology can set off more complex market dynamics too.

\subsection{Improving management}

The Internet affects the book retail market not only individuals but also inside companies. The internet is the most powerful tool available today for enhancing effective management. Traditional book retail company have to think about how to run their businesses effectively in the internet age. They may join in the internet world or improve management. For example, in Britain book retail market, Internet retailing is booming, profits at Waterstone's, the biggest British bookseller, are up $11 \%$ during five years. How can they achieve that huge success? Faced with the threat from the Internet market, management has been improved inside company. Waterstone's as the traditional bookseller has also been changed. On one side, their mission is to be the leading bookseller on the high street and also online providing customers the widest choice, great value and expert advice from a team passionate about bookselling. (http://www.waterstones.com/watersonesweb/) On other side, supply chains have been streamlined and some of the more unworthy staff has been replaced. Customers are lured in with special deals on bestsellers, which are used as hooks to sell tomes from publishers' back catalogues.

\section{Conclusion}

Many business booksellers and publishers now offer the opportunity to buy through a web site. These sites have become increasingly popular for finding backlist and harder to find titles that bookshops don't always have in stock. This is also a useful way of drawing customers into learning more about the companies' organization and the other areas in which company publish. From the customer's point of view, it's easy to access to a site that offers lower prices, easier ordering system and delivery with a click of a button.

However there are the limitations of the Internet as a retail channel. Internet firms can often undercut their high street rivals, but customers must wait at least a day for their goods to be delivered, often at inconvenient times. "Amazon is very good at distribution," says Rob Mann, an analyst at HSBC. "But there's still the idea of instant satisfaction. On that front, internet retailers will always be at a disadvantage." And while low prices attract customers who know exactly that they're looking for, browsers tend to prefer real shelves full of real books to a computer screen and a mouse. "A lot of people go into a bookshop not really knowing what they want," says Mr. Mann. "It's difficult to do that online." So how to solve that problem it's the main issue for the Internet book retail market in the future.

In my point of view, the Internet affects the book retail market from cost, price and inside company. I do see the future including the downloading of a particular book in a formatted file of some kind. It's inevitable trend in the book retail market. However Internet can't destroy the traditional booksellers. I don't think that the actual physical book will be disappearing.

\section{References}

Baker, Walter; Mike Marn and Craig Zawada. (February 2001) Price Smarter on the Net, Harvard Business Review.

Bookshops and internet retailing: the internet was supposed to destroy off-line booksellers. It hasn't, (Dec 2004). 
[Online] Available from htt://Economist-com.htm

Garicano, Luis and Steven Kaplan (2001) "The Effects of Business-to-Business E-Commerce on Transaction Costs" Forthcoming Journal of Industrial Economics.

Higgins Les (2000), how to market books, London, Alison Baverstock, $3^{\text {rd }}$ edition, p173-p183.

Jeffrey F.rayport and Bernard J.jaworski (2001), introduction to e-commerce, California, Publisher: John E. biernat

Lucking-Reiley, David and Daniel Spulber (2001) Business-to-Business Electronic Commerce, Journal of Economic Perspectives.

Michael E.Porter (March, 2001), Strategy and the Internet, Harvard Business Review.

The internet for the book professions, [Online] Available: http://www.inasp.org.uk/psi/bmp/ibp-pubs.htm

What's the E-commerce, [Online] Available: http://www.free-web-hosting-plan.com/ecommerce-newbies. htm 